Print ISSN: 2233-4165 / Online ISSN: 2233-5382

doi: http://dx.doi.org/10.13106/jidb.2013.vol4.no2.5.

\title{
Reforming Accounting Education Content to Fulfill Business Environment Needs*
}

\author{
Mahdi Salehi**, Farzaneh Nassir Zadeh***, Mohammad Javad Saei****, Vahab Rostami*****
}

\section{Abstract}

Purpose - Considering the importance of education as the base for countries' development, the results of various studies show that accounting education is not reconciled to business environment changes with huge defects in methods of education and knowledge transition.

Research design, data, and methodology - By reviewing current research and considering the effect of 12 factors, the study traces and detects why accounting education is far from the business environment from viewpoints of academic and practitioner bodies. After testing for validity and reliability, 225 questionnaires were administrated among representatives of three groups.

Results - Respondents were not satisfied with lack of specification of various scientific areas of accounting, that less attention is paid to accounting software education, and about the rarity of workshops for performing accounting skills and discordance between accounting education and standard rules.

Conclusion - These findings agreed with Albrecht and Sack (2001) who stated that the current style of accounting education is very cluttered and incomplete and needs major adjustments: subjects of accounting education must be based on the grounds of work needs not on willing academics.

Keywords : Education Content, Education Ways, Education Topic, Business Environment Needs, Expertise Viewpoint.

JEL Classifications : M41, M42, M49.

* The authors gratefully acknowledge the financial support from the Ferdowsi University of Mashhad, Mashhad, Iran.

** Corresponding Author, Accounting Department, Ferdowsi University of Mashhad, Iran, E-mail: Mehdi.salehi@um.ac.ir.

*** Accounting Department, Ferdowsi University of Mashhad, Iran.

**** Accounting Department, Ferdowsi University of Mashhad, Iran.

***** Department of Economics and Social Science, Payame Noor University, PO BOX 19395-3697 Tehran, Iran.

\section{Introduction}

Nowadays education element is considered as the most important development factor of each country. Upon that a new definition is proposed for the capital which differs from those the wealth's; and while wealth of the countries is considered as total tangible resources and mines and suitable climatic conditions same as good geographical location, real properties and capital of the countries consist of the educated and specialist labour whom by its good performance make improvement and growing economic condition of their countries and accumulation of the national wealth. Referring to an Arabic banker saying, due to our deficiency to access specialist labour, besides owning huge amount of oil reserves, we are like as an child orphan who has inheritance a big gold but cannot gain of it by ourselves, has more reveals the importance of this topic. Hence, one of the main attitudes of each country is establishing a suitable educational system to train requested labour to handle various duty at society which this task is surrounded to schools and academics that are performing general and spatial education courses respectively. By considering the importance of correct education of human resource as base of the development, many countries has done many activities and tried to improve the efficiency of academic education and this subject has get more attention in recent years. The main mission of universities in each country is training and preparing specialists and required labour in business environment upon that, at the first step it must be identified the business environment labour needs and after that by sophisticated planning peruse students to acquire the required skills and expertise of the work environment. Unfortunately, various studies and investigations around this topic indicates the most academic educational courses is going far from real labour needs of the society and have lost its stated mission and in many cases, it is required the students after graduation pass the additional training courses to take necessary abilities along surrounded duties. This case makes wasting the time and in some academic fields such as accounting is more evident.

\section{Research Problem}

Due to changes in the business environment such as rapid technological development and globalization of markets, the role 
of current accountants from preparing the financial information has been changed to providing and interpreting variety of information, including financial and non-financial to users within the organizations same as outside the organizations (Sandom, 1992; Williams, 1994; Albrecht and Sack, 2000). Such changes in the business environment has revealed the need for change and redefining the role of the accounting profession more than ever and it requires that accounting graduates should have the knowledge and required skills to meet expectations of the business community which is continuously changing. By considering the main objective of accounting education programs which is preparing students to success in exams and gain qualifications for entry into the accounting profession, several studies demonstrate the inability of the education system to practice his calling duties and training the qualified accountant to handle them surrounding financial affairs. Hence firstly accounting could not to up to date its rules along other scientific fields and secondly, there is also evident deficiency in the ways of training and appropriate transferring these rules to accounting students in universities. In summary, while on the one hand, we are encountered with a surplus of ready for work with accounting degree, in contrast on the other hand there are employers in the work place who have complained about the lack of qualified accountants. Hence most of these studies, suggest necessity and significance of accounting education programs reform. In this regard, Albrecht and Sack $(2000,2001)$ state that it is not the appropriate time for a change in accounting education to just get "better" and it is over. The current structure of provided accounting education is desolate and imperfect and requires fundamental reforms. Accounting educational course should be based on market demand, not according to the interests of universities. The purpose of accounting science is not accounting education, but also is training the students that become accountant. According to many studies, one of the fundamental problems in accounting is that there is no effective and constructive interaction between accounting studies, accounting education and the accounting profession (Albrecht and Sack, 2000; Chaber and Hwy, 2001; Forrestal, 2002, Boyce, 1999). This weakness is caused the adverse consequences in condition of research, education and the accounting operation. Today, the gap between the accounting profession and accounting education has gradually broadened and members of the profession face with complex and unexpected situations so that for passing through this position, they must be equipped with special skills. And In the moment time, these efforts to decrease the gap between the profession and accounting education have become an important topic. Acquiring special skills are influenced by education and accordingly it shows necessity to changes or revisions of the accounting education. The main objective of the current ways of accounting education is training accountants who have flexibility in terms of the ability to take new and appropriate solutions in encountering with changes in status. Also, there has been less attention to the problem solving skills in classic accounting education program while it is more attention in the new phase accounting education (Click and Esser, 2009). Nowadays, accounting graduates, whom their majority of university training is restricted to the learning correct way of bookkeeping, are expected to handle challenges of data bases, computer software, tax rules, insurance, and laws, while there is overall agreement that most of them are not too educated along forgoing topics. By knowing that the major characteristics of evaluation countries development came back to abilities of those society in knowledge production process; current study is willing to trace the main difficulties of accounting education process in Iran and after that providing practical solutions to deal with these attitudes. It sought to identify and document viewpoint of main groups engaged including academics and profession bodies around major field of that makes a gap between the needs of the society and education of academic accounting, it includes following three distinct areas:

Firstly, how much the content of the current accounting textbooks is appropriate with needs of the work place?

Secondly, how much accounting training and education program content is in accordance with needs of current academic education?

And finally how much do the outline and the structure of accounting courses need revision according to the needs of today's society?

\section{History of Accounting Education in Iran}

Traditional argument of accounting has a long history in Iran. But the using new double bookkeeping system in Iranian entities and government states come back to 70 years ago. Firstly using of this system was common by foreign companies that have offices or branches in Iran, but it's subsequently usage inters into local companies as well. Iranian Shahi Bank and national oil company were the country's first users of this system. Active participation of Iranians in the accounting profession come back to 1935 , in which 12 Iranian students were sent to England to study new accounting science with the scholarship of Iranian National Bank. After that other organizations such as the treasury Ministry and Iranian National Oil Company also followed similar programs that subsequently 150 accounting students get benefited from the program. So far the course of accounting is established in most Iranian state and private universities and some of them are training students in master and Ph.D. course.

\section{Literatures review}

Bedford Committee (1986) concluded that in United States, accounting is getting to become a wide informative profession which uses increasingly from measurement techniques, sophisticated and complex analytical concepts and new communication tools to improve the provided information in making widespread economic and social decision. Bedford and Shinker's report 
(1987) was essentially based on this issue that Accounting Education has remained unchanged yet and this is why there is widespread criticism about inability of accounting graduates to take good communication and know how to argue logically. The report also claimed that accounting students' communication skills are often weak and they cannot be creative and thinking responsibly. Hence the committee recommended accounting education process must be restructured and divided into three courses. First two years of them must be allocated to general education of accounting concepts and then two other years to professional accounting education and last courses is better to allocate to spatial accounting education. In 1989, with the formation of the Accounting Education Committee (AECC) it conclude that the accounting traditional education approach heavily depended mainly on technical computing of a correct answer which needs to changes and improve this process immediately.

Night and Zook (1982) reported in their study which two investigated groups including Certified public Accountants and American financial managers ranked differently the importance of some of the financial and management accounting topics.

In same direction, Novin, Pearson and Sedghi (1990) studied the required skills and attributes for accounting graduates in order to inter to management accounting careers to provide useful curriculum.

Siegel and Sorenson (1994) studied to find answer about what skill do united states companies expect of new accountants which have been recently jointed to this career, and they show academics training for a career in management accounting are not adequate to cope with needs and there is need to establish a link between the university and the professional staff so make a connection between these two groups ideas. In this regard, Siegel and Kulisa (1995) in the other study documented that accounting graduates in U.S. companies do not have the ability to solve critical issues of management accounting and corporate managers have tendency to be taught accounting course based on what they are doing as accounting management in real situations. Mc Pail (1999) by focus on necessarily on training communication skills and ethical code, stated that financial college do not persistence on their responsibilities to prepare students to meet and deal with complicated problems, especially ethical ones in real world. In 1992, the International Federation of Accountants issued a statement titled Code of Professional Conduct, education challenges and practical application that accordance to, accounting education courses should include Code of Professional Conduct to motivate students to behave in ethical manner. Later the Federation released the Survey results around necessity of Ethical Education in Accounting which shows there is a positive feedback regarding the need for and scope of ethical education throughout the world (Selvi, 2000). In same direction Rainer and Tanner (2001) reported there is an urgent need that accounting teachers change their teaching method and include marketing and communication concepts and more over ethical rules into the accounting curriculum in order to reduce its gap with real word needs. Nearon (2002) also presents evidence that accountants have been lost their former privilege and honor in the society and now they have to give it back in the markets'recent scams. $\mathrm{He}$ have idea that it should be taught to students the financial accounting principles which presented in theory of financial reporting, and they must also learn issues related to ethical code and professional auditing standards and internal controls related to fraud. In this regard Caliyurt (2004) focuses on the ethical implications of teaching after the collapse of giant energy, Enron, in public universities in Turkey and showed that contrary to the initial impression, coefficient attention to moral concepts education in that country is low. Sultan Oglu (2007) also examined education program units of accounting in Turkey and states that there is no main difference in the style and type of accounting academic education in Turkish universities and those in United States', Nevertheless, he also noted the consequences of lack of moral education units.

Also Mohamad and Lashin(2003) survey result showed that, nowadays current model of accounting education in universities is not adequate to prepare students to enter today's complex markets and Accounting teachers need to develop a strategic plan to reduce the gap between the students' current skills and their required skills.

Karr (2005) in his research suggests that accounting graduates should possess adequate strong training features and communication skills. He concluded in their study, that Practitioners place great emphasis on the reporting skills of graduates.

Kramer et al. (2005) also documented that many accounting graduates are ineligible to be an accountant in public and private sectors and lacking link between academics and practitioners is its main reason.

Jane Smith (2000) by assessing differences in educational priorities in an undergraduate course revealed that financial managers and accounting practitioners dissatisfied with low-skill graduates and this dissatisfaction can arise from perceptual gap between professional practitioners and educators and both dissatisfaction of their jobs. He suggested that university professors and professional staff to have consultation in order to revise the accounting curriculum and ensure that the course would respond to students'needs and employers. He states in his study that American Institute of CPAs want to change the accounting curriculum and reforming accounting courses in order to satisfy market demands and the lack of communication and discussions on how to improve teaching and course among professors are the major obstacles to promotion and establishment fundamental changes in the course.

\section{Research hypotheses}

In order to achieve the research objectives, the following hypotheses based on the theoretical foundation designed and presented: 
First hypothesis: from perception of respondents, the current contents of accounting educational books are not in accordance with the needs of work place and graduates.

Second hypothesis: from perception of respondents, current methods of presenting and training (education) of the accounting concepts are not in accordance with the needs of work place and graduates.

Third hypothesis: from perception of respondents, curriculum and academic units of accounting for graduates in these fields is not in accordance with the needs of the work place.

\section{Research methodology and data collection methods}

As regards, current research sought to trace the major factors causing the gap between academic education of accounting and work place needs; it is classified upon its goal as applied research. In addition, this study since do not want to assess the impact of changing one variable (the independent variable) on another variable (the dependent variable) and Just want to clarify the situation in the society, around methodology of the research is classified as descriptive research. According to the study, this seeks to trace the major effective factors in increasing efficiency of accounting education units in universities. The statistical sample includes of members of the academic community, professional association and practitioners of work place and due to the wide range of people involved in this process, sampling particularly through the representatives of these three groups were followed as:

$<$ Table 1> Population and sample of the study

\begin{tabular}{|l|c|}
\hline Investigated population & Representative agents \\
\hline \multirow{2}{*}{ Academic community } & University Professors \\
\cline { 2 - 2 } & B.A and M.A accounting students \\
\hline \multirow{2}{*}{ Profession community } & Auditors \\
\cline { 2 - 2 } & Supreme Audit Court experts \\
\hline \multirow{3}{*}{ Practitioners community } & Accountants \\
\cline { 2 - 2 } & Financial managers of companies \\
\cline { 2 - 2 } & Tax organization Experts \\
\hline
\end{tabular}

For selection of the wanted sample the simple random method was used upon that the result of the study can be generalized to whole of the investigated population members. Due to an unlimited number of populations and also the study data being in quality manner similar to same research procedures, we considered $\mathrm{P}=0.5,1-\mathrm{P}=0 / 5$ and the measurement accuracy of $€$ $=8 \%$ and sample size in the $95 \%$ confidence intervals, were calculated as follow:

$$
n=\frac{z p(1-p)}{\epsilon^{2}}=\frac{1.96 \times .5(1-.5)}{0.08}=230
$$

In addition, to avoid prejudicing results of research caused by differences in studied sample size of the different studied groups and to maintain a balance between the different investigated groups is tried to be selected equal numbers of samples from each group (80 cases) and finally was collected wanted information.

In current study level of the analysis is the macro and unit of the analysis is human. With regard to research methodology and the qualitative nature of research, questionnaire is the most appropriate tools for gathering data. Accordingly, we use a questionnaire with five options Likert spectrum (strongly agree, agree, no opinion, disagree, completely disagree) to assess the general condition of the factors from view point of the respondents'. The questioner includes two separate sections of general questions about status of the respondents, including their age, gender and educational level and more over 32 questions about the current gap between accounting education and accounting practice in the three investigated areas of study hypotheses. Before distributing the questionnaires, the validity of it is ensured by utilizing views of experts and accounting professors and Delphi method. While Cronbach's alpha statistical method is used to assess its reliability and approximately 45 questionnaires was distributed among some of investigated respondents and the results were collected. Coefficient alpha for the initial sample was calculated as 0.97. However Values above 0.7 for coefficient alpha indicate the acceptable reliability of data collecting tools. Table No. 2 shows the number of research areas, allocated questions to each area and Cronbach's alpha coefficients for each factor in detail:

According to the five-choice Likert scale to measure respondents' satisfaction, to acceptation of the hypotheses the mean responses of respondents must be more than three. However the statistical expression of each hypothesis is followed as below:

First hypothesis: from perception of respondents, the current contents of accounting educational books are not in accordance with the needs of work place and graduates (the average of concurrent responds in likert five options will be more than three).

$$
\begin{array}{ll}
\mathrm{H} 0: & \mu 1 \leq 3 \\
\mathrm{H} 1: & \mu 1>3
\end{array}
$$

\section{Hypotheses test results}

However, approximately out of 300 questionnaires were distributed among the research respondents while finally 225 complete and usable questionnaires were returned. Table No. 3 shows the respondents' General Information: 
$<$ Table 2> Relation among research hypotheses with each area of study and allocated questions

\begin{tabular}{|c|c|c|c|}
\hline $\begin{array}{l}\text { Research } \\
\text { Hypotheses }\end{array}$ & $\begin{array}{c}\text { Investigated area of each } \\
\text { hypothesis }\end{array}$ & $\begin{array}{l}\text { Number of } \\
\text { questions }\end{array}$ & $\begin{array}{c}\text { Cranach's } \\
\text { Alpha }\end{array}$ \\
\hline $\begin{array}{l}\text { Appropriateness } \\
\text { of the current } \\
\text { contents of } \\
\text { accounting } \\
\text { educational } \\
\text { books with } \\
\text { need of work } \\
\text { place }\end{array}$ & $\begin{array}{l}\text { Investigating the necessity to } \\
\text { inclusion of a separate course } \\
\text { around accounting standards } \\
\text { for student } \\
\text { Investigating the necessity to } \\
\text { inclusion a separate training } \\
\text { course for accounting required } \\
\text { rules such as business, tax } \\
\text { and retirement and so on } \\
\text { rules. } \\
\text { Investigating the necessity to } \\
\text { inclusion a separate training } \\
\text { course to training code of } \\
\text { conduct to improve students' } \\
\text { ethical behaving abilities. }\end{array}$ & 3 & 0.872 \\
\hline $\begin{array}{l}\text { Appropriateness } \\
\text { of the current } \\
\text { methods of } \\
\text { presenting and } \\
\text { training } \\
\text { (education) of } \\
\text { the accounting } \\
\text { concepts with } \\
\text { need of work } \\
\text { place }\end{array}$ & $\begin{array}{l}\text { Review the need to passing } \\
\text { novitiate courses by students } \\
\text { Review the need for } \\
\text { incorporation accounting } \\
\text { practical education workshops } \\
\text { Review the need for attend } \\
\text { accounting information system } \\
\text { design courses for a sample } \\
\text { company } \\
\text { Review the need for taking } \\
\text { practical qualification certificate } \\
\text { by whom is teaching } \\
\text { accounting in universities. }\end{array}$ & 3 & $\begin{array}{l}0.771 \\
0.769 \\
0.876 \\
0.765\end{array}$ \\
\hline $\begin{array}{l}\text { Appropriateness } \\
\text { of the current } \\
\text { curriculum and } \\
\text { academic units } \\
\text { of accounting } \\
\text { with need of the } \\
\text { work place }\end{array}$ & $\begin{array}{l}\text { Investigating the necessity to } \\
\text { specializing accounting training } \\
\text { course to separate fields } \\
\text { including financial accounting, } \\
\text { cost accounting, accounting } \\
\text { for not for profit seeking } \\
\text { organization and auditing and } \\
\text { so on. } \\
\text { Investigating the necessity to } \\
\text { inclusion of educational units' } \\
\text { about accruing suitable skill } \\
\text { around one accounting } \\
\text { software } \\
\text { Investigating the necessity to } \\
\text { inclusion of learning } \\
\text { administrative communication } \\
\text { skill by students. } \\
\text { Investigating the necessity to } \\
\text { inclusion of courses for } \\
\text { introducing the operation of } \\
\text { network, database and } \\
\text { accounting information system } \\
\text { Investigating the necessity to } \\
\text { existence of accounting test } \\
\text { for granting of license } \\
\text { certificate for accountant to } \\
\text { work in business environment. }\end{array}$ & 2 & 0.735 \\
\hline
\end{tabular}

$<$ Table 3> General Information of respondents

\begin{tabular}{|c|c|c|c|c|c|}
\hline Age & $\begin{array}{c}\text { Freque } \\
\text { ncy }\end{array}$ & $\begin{array}{c}\text { Perc } \\
\text { ent }\end{array}$ & Working area & $\begin{array}{c}\text { Frequen } \\
\text { cy }\end{array}$ & $\begin{array}{l}\text { Perc } \\
\text { ent }\end{array}$ \\
\hline Less than 25 & 35 & 0.16 & Acc. teachers & 29 & 0.13 \\
\hline 25 to 35 & 107 & 0.48 & Students & 72 & 0.32 \\
\hline 35 to 45 & 58 & 0.25 & Auditors & 25 & 0.11 \\
\hline More than 45 & 25 & 0.11 & Supreme Audit experts & 10 & 0.04 \\
\hline experience & $\begin{array}{c}\text { Freque } \\
\text { ncy }\end{array}$ & $\begin{array}{c}\text { Perc } \\
\text { ent }\end{array}$ & Accountants & 55 & 0.25 \\
\hline Less than 5 & 98 & 0.35 & Financial managers & 18 & 0.08 \\
\hline 6 to 10 years & 106 & 0.38 & Tax experts & 16 & 0.07 \\
\hline 11 to 15 years & 42 & 0.15 & Education & $\begin{array}{c}\text { Frequen } \\
\text { cy }\end{array}$ & $\begin{array}{l}\text { Perc } \\
\text { ent }\end{array}$ \\
\hline More than 15 & 35 & 0.12 & Bachelor & 136 & 0.61 \\
\hline Field of Study & $\begin{array}{c}\text { Freque } \\
\text { ncy }\end{array}$ & $\begin{array}{c}\text { Perc } \\
\text { ent }\end{array}$ & Masters \& PhD & 89 & 0.39 \\
\hline Accounting & 160 & 0.71 & Gender & $\begin{array}{c}\text { Frequen } \\
\text { cy }\end{array}$ & $\begin{array}{l}\text { Perc } \\
\text { ent }\end{array}$ \\
\hline Management & 45 & 0.20 & Male & 147 & 0.65 \\
\hline Economics\& etc. & 20 & 0.09 & Female & 78 & 0.35 \\
\hline
\end{tabular}

As the table shows $65 \%$ of respondents are male, and 60 percent have a bachelor's degree, and also 70 percent of them have studied accounting. However table No. 4 below shows the results of testing hypotheses:

$<$ Table 4> Research hypotheses test result

\begin{tabular}{|c|c|c|c|c|c|c|}
\hline Hypothesis & $\begin{array}{c}\text { Subject of } \\
\text { hypothesis }\end{array}$ & $\begin{array}{c}\text { Mean of } \\
\text { answers } \\
\mu\end{array}$ & $\begin{array}{c}\text { SD of } \\
\text { answers } \\
\delta\end{array}$ & $\begin{array}{c}\text { Test } \\
\text { statistic } \\
\text { T }\end{array}$ & Sig. & $\begin{array}{c}\text { Test } \\
\text { result }\end{array}$ \\
\hline $\begin{array}{c}\text { The first } \\
\text { hypothesis }\end{array}$ & $\begin{array}{c}\text { Accounting } \\
\text { Educational } \\
\text { textbooks } \\
\text { are not } \\
\text { updated }\end{array}$ & 4.3176 & 0.4205 & 2.0322 & 0.015 & $\begin{array}{c}\mathrm{H} 0 \\
\text { rejected }\end{array}$ \\
\hline $\begin{array}{c}\text { The } \\
\text { second } \\
\text { hypothesis }\end{array}$ & $\begin{array}{c}\text { Educational } \\
\text { methods of } \\
\text { accounting } \\
\text { are not } \\
\text { updated }\end{array}$ & 4.1180 & 0.2973 & 2.0507 & 0.006 & $\begin{array}{c}\mathrm{H} 0 \\
\text { rejected }\end{array}$ \\
\hline $\begin{array}{c}\text { The third } \\
\text { hypothesis }\end{array}$ & $\begin{array}{c}\text { Accounting } \\
\text { Educational } \\
\text { syllabi are } \\
\text { not } \\
\text { updated }\end{array}$ & 4.4697 & 0.3011 & 1.9843 & 0.038 & $\begin{array}{c}\mathrm{H} 0 \\
\text { rejected }\end{array}$ \\
\hline
\end{tabular}

As mentioned above about these three hypotheses, the significance level is less than $5 \%$ error level. Based on these hypotheses, $\mathrm{HO}$ is rejected and there is evidence that shows from view point respondents, three aforementioned factors cause the gap between academic training in accounting and work place needs.

Further to clarify the importance of each fields in the forgoing gap between education and practice, existence of significant difference among 12 studying areas in hypotheses were also tested by Kruskal Wallis test as follows: 
$\mathrm{HO}: \mu 1=\mu 2=\ldots=\mu 12$

$\mathrm{H} 1$ : There is at least one that its mean is different from the rest

Where $\mu 1$ to $\mu 12$ represents participants' responses' average about the importance of each 12 areas of accounting which make a gap between accounting education and its' practice.

By considering the ordinal scale of study data, we use nonparametric Kruskal-Wallis statistical methods to test our research and the results are presented in table No. (5) below:

$<$ Table 5> Kruskal-Wallis test result

\begin{tabular}{|c|c|c|c|c|c|}
\hline $\begin{array}{c}\text { Number } \\
\text { of areas }\end{array}$ & $\begin{array}{c}\text { Number of } \\
\text { replies of } \\
\text { each group }\end{array}$ & $\begin{array}{c}\text { Chi-square } \\
\text { value }\end{array}$ & D.f & P-Value & $\begin{array}{c}\text { Test } \\
\text { result }\end{array}$ \\
\hline 12 & 225 & 101.539 & 11 & 0.000 & $\begin{array}{c}\mathrm{H}_{0} \\
\text { rejected }\end{array}$ \\
\hline
\end{tabular}

Kruskal-Wallis test result shows that P-Value is less than significant level of 5 percent, so $\mathrm{HO}$ is rejected and $\mathrm{H} 1$ hypothesis that refers to differences between the 12 areas is accepted. To determining the areas have the greatest effect to them which is less impact in creating gap between accounting education and work place needs from viewpoint of respondents we used Friedman ranking statistical methods. The statistic value of the test is less than the significance level of $5 \%$. Ranking result of forgoing 12 areas is presented in table No. 6 below:

$<$ Table 6> Results of Friedman test result to ranking importance of forgoing 12 areas

\begin{tabular}{|c|c|c|}
\hline Investigated areas of the hypotheses & $\begin{array}{l}\text { Answers } \\
\text { Mean }\end{array}$ & $\begin{array}{l}\text { Raking } \\
\text { result }\end{array}$ \\
\hline $\begin{array}{l}\text { The need for teaching accounting } \\
\text { standards }\end{array}$ & 4.762 & 5 \\
\hline $\begin{array}{l}\text { The need for teaching business, tax and } \\
\text { insurance rules }\end{array}$ & 4.809 & 4 \\
\hline $\begin{array}{l}\text { The need for training moral concepts and } \\
\text { code of conduct }\end{array}$ & 3.495 & 11 \\
\hline $\begin{array}{c}\text { The need to passing novitiate courses by } \\
\text { students }\end{array}$ & 4.835 & 3 \\
\hline $\begin{array}{l}\text { The need to incorporation accounting } \\
\text { practical education workshops }\end{array}$ & 4.703 & 6 \\
\hline $\begin{array}{l}\text { The need for attending accounting } \\
\text { information system design courses }\end{array}$ & 2.953 & 12 \\
\hline $\begin{array}{l}\text { The need for taking practical qualification } \\
\text { certificate by teacher }\end{array}$ & 3.981 & 8 \\
\hline $\begin{array}{l}\text { The need to specializing accounting } \\
\text { training course to separate fields }\end{array}$ & 5.183 & 1 \\
\hline $\begin{array}{c}\text { The need for introduction an accounting } \\
\text { software }\end{array}$ & 4.970 & 2 \\
\hline $\begin{array}{l}\text { The need to teaching administrative } \\
\text { communication skill }\end{array}$ & 4.648 & 7 \\
\hline $\begin{array}{c}\text { The need for introduction of network and } \\
\text { database }\end{array}$ & 3.393 & 9 \\
\hline $\begin{array}{l}\text { The need for passing an qualification } \\
\text { exam to inter work }\end{array}$ & 3.508 & 12 \\
\hline
\end{tabular}

As Friedman test result, respondents among the 12 causative of gap between accounting education and market needs pointed that the most impotence factors are: don't attending to the specialization of accounting fields, negligence to providing education related to accounting software, lack of novitiate courses, negligence to extended training for tax, insurance, business and rules, and non-compliance with accounting standards, while in their idea, the need for training the designing accounting information system, the need for providing moral training and finally passing an qualification exam to inter work are less effective in making this gap form viewpoint of respondents.

\section{Conclusions and Recommendations}

By considering the importance of the optimal education of the human resource as the base of the countries developments, many efforts have been done to improve the academic education efficiency in recent years. But several studies result in recent years show this bad truth that, in most of the times, current academic education failed to achieve its educational mission due to its don't accordance to real work place needs. Findings in this area often refer to inability of accounting to keep pace with advances in other fields of science; secondly there is also a probable vacuum in the method of teaching transferring this data of accounting to students at universities. In other words, while we are encountered with a surplus of graduate with accounting degree, on the other hand there are employers in the markets who complain about the lack of qualified accountants. Several studies have been done in recent years to identify the deficiencies and fill the vacuum. Several studies have been done in recent years to identify main factors causing the gap between educations and accounting practice from viewpoint of academic and profession bodies. Current research findings suggest that among 12 causative of gap between accounting education and market needs pointed don't attending to the specialization of accounting fields, negligence to providing education related to accounting software, lack of novitiate courses, negligence to extended training for tax, insurance, business and rules, and non-compliance with accounting standards,, while in their idea, while in their idea, the need for training the designing accounting information system, the need for providing moral training and finally passing an qualification exam to inter work is less effective in making this gap. In contrast to wasn't updating the content of accounting textbooks and wasn't updating accounting educational syllabi respondents are referred much more to need to updating and changing in ways and methods of accounting education. However this finding is in accordance with previous research finding of Albrecht and Sack (2001) which state the time for change in accounting education just to get "better" is passed. The current was presented structure of accounting education is remote and imperfect and require fundamental reforms, accounting course should be based on market demand, not according to the interests of universities. The pur- 
pose of accounting is not accounting education, but it is training students as accountants. Presenting education in an unspecialized and expert way led to be graduation of the students which don't have adequate required skills.

Received: October 04, 2013.

Revised: October 22, 2013.

Accepted: December 16, 2013.

\section{References}

Albrecht, S. V., \& Sack, RJ., (2000). Accounting Education: Charting the Course Through a Perilous Future. American Accounting Association, 16, 693-703.

Albrecht, S. V., \& Sack, RJ. (2001). The Perilous future of accounting education. The CPA Journal, 71(3), 16-23.

Caliyurt, K. T. (2004). Accounting Ethics Education in Turkish Public Universities. Social Responsibility Journal, 3, 74-80.

Gene, L. Smith (2006). Determining differences in the preferred undergraduate accounting curriculum among students, practitioners and educators. Ph.D. thesis, North Central University, Arizona.

Karr, S. (2005). Is Accounting Education Relevant? Many are questioning the Quality- not to mention the Quantity- of Accounting Graduates and their Abilities to Handle the on Slough of Complex Transactions and Technical Regulations. Are the Schools- and the StudentsPreparing for Accounting in the Real word?. Financial Executive, 21, 40-42.
Knight, R.E., and Zook, D.R. (1982).Controllers and CPAs evaluate the relevance of education topics. Management Accounting, 64 (5), 30-34.

Kramer, B. K. P., Johnson, C. W., Crain,G. W., and Miller, S. J. (2005). The practitioner-professor link. Journal of Accountancy, June, 77-80.

McPail, K. (1999). The threat of ethical accountants: an application of Foucault's concept of ethics to accounting education and some thoughts on ethically educating for the other. Critical Perspectives on Accounting, 10, 833-866.

Mohamed, E. K. A., \& Lashine, S. H. (2003). Accounting knowledge and skills and the challenges of a global business environment. Managerial Finance, 29, 3-17.

Nearon, B. (2002). A professional argues for higher education standards. The CPA Journal, 73(1), 17-22.

Novin, Pearson \& Sedge, P. M. (1990). Improving the curriculum for aspiring management accountants: The practitioner's point of views. Journal of Accounting Education, 8, 96-109.

Renner, C., \& Tanner, M. (2001). Educating future accountants: Alternatives for meeting the ISO- hour requirement. Journal of Education for business, 76(3), 132-137.

Selvi, Y. (2000). Ahlak Kurallari ve Muhasebe Etigine Etkileri. Muhasebe ve Finansman Dergisi, (8), 60-71.

Siegel, G., \& Kulesza, C. (1995). Are accounting students ready for corporate America? Special Report. Management Accounting, 76, 19-50.

Siegels, G., \& Sorenson, J.E. (1994). What corporate America wants in entry level accountants?. Management Accounting, 76(3), 26-31. 